\title{
Fabrication and characterization of glass with E-glass fiber composition by using silica-alumina refused coal ore
}

\author{
Ji-Sun Lee***, Tae-Young Lim*,†, Mi-Jai Lee*, Jonghee Hwang*, Jin-Ho Kim* and Soong-Keun Hyun** \\ *Korea Institute of Ceramic Engineering and Technology, Optic \& Display Material Team, Seoul 153-801, Korea \\ **Department of Materials Science and Engineering, Inha University, Incheon 402-751, Korea \\ (Received August 1, 2013)
}

(Revised August 9, 2013)

(Accepted August 14, 2013)

\begin{abstract}
The glass of E-glass fiber composition was fabricated by using refused coal ore which is obtained as by-product from Dogye coal mine in Samcheok. We used silica-alumina refused coal ore which has low carbon content relatively, and the amount of refused coal ore has been changed from 0 to $35 \%$ in batch composition. E-glass was fabricated by the melting of mixed batch materials at $1550^{\circ} \mathrm{C}$ for $2 \mathrm{hrs}$ with different refused coal ore composition of $0 \sim 35 \%$. We obtained a transparent and clear glass with high visible light transmittance value of $81 \sim 84 \%$, thermal expansion coefficient of $5.39 \sim 5.61 \times 10^{-6} \rho^{\circ} \mathrm{C}$ and softening point of $851 \sim 860^{\circ} \mathrm{C}$. The glass fiber samples were also obtained through fiberizing equipment at $1150^{\circ} \mathrm{C}$, and tested chemical resistance and tensile strength to evaluate the mechanical property as a reinforced glass fiber of composite material. As the result, we identified the properties of E-glass fiber by using refused coal ore are plenty good enough compare to that of normal Eglass without refused coal ore, and confirmed the possibility of refused coal ore as for the raw material of E-glass fiber.
\end{abstract}

Key words Refused coal ore, Glass fiber, E-glass, tensile strength, Softening point

\section{사암계 석탄폐석을 활용한 E-glass fiber 조성의 유리 제조 및 특성}

\author{
이지선***, 임태영*,, 이미재*, 황종희*, 김진호*, 현승균** \\ *한국세라믹기술원 광디스플레이소재팀, 서울, $153-801$ \\ **인하대학교 금속공학과, 인천, 402-751
}

(2013년 8월 1일 접수)

(2013년 8월 9일 심사완료)

(2013년 8월 14일 게재확정)

요 약 삼척도계지역의 탄광에서 석탄채굴시에 부산물로 발생되는 사암계 석탄폐석을 원료로 사용하여 E-glass fiber 조성의 유리를 제조하였다. 본 연구에서는 카본함량이 비교적 적은 실리카-알루미나질의 사암계 석탄폐석을 사용하였으며, 폐석의 투입량을 0 35\%까지 변화시켰다. 서로 다른 석탄폐석 투입량을 갖는 배치원료를 $1550^{\circ} \mathrm{C}$ 에서 2 시간 용융하여 $\mathrm{E}-$ glass조성을 갖는 투명하고 맑은 유리가 얻어졌고, 81 84\%의 높은 가시광투과율, $5.39 ~ 5.61 \times 10^{-6} \mu^{\circ} \mathrm{C}$ 의 열팽창계수, 851 $860^{\circ} \mathrm{C}$ 의 연화점을 나타내었다. 유리섬유 시편은 $1150^{\circ} \mathrm{C}$ 에서 섬유인상장치를 통해 얻어졌고, 복합재료의 보강용 유리섬유로 서 내화학성 시험과 기계적 특성평가를 위한 인장강도를 측정하였다. 그 결과 석탄폐석을 사용한 E-glass fiber의 특성이 석 탄폐석을 사용하지 않은 보통 E-glass 섬유에 비해 충분히 양호한 특성을 나타내어 E-glass 섬유용 원료로서 석탄폐석의 활 용가능성을 확인할 수 있었다.

\section{1. 서 론}

탄광에서 석탄채굴시에 부수적으로 발생하는 석탄폐석 은 그동안 마땅한 재활용방법이 개발되지 않았고, 단순

\footnotetext{
Corresponding author

Tel: $+82-2-3282-2426$

Fax: +82-2-3282-7814

E-mail: tylim@kicet.re.kr
}

매립처리도 어려운 실정이어서 탄광지역 주변에 야적상 태로 방치되면서 주변경관 훼손과 함께 자연환경의 위해 요인이 되고 있다. 그동안 폐자원에 대한 재활용 연구는 주로 화력발전소에서 발생하는 석탄회나 하수 슬러지 등 을 이용하여 인공경량골재를 제조하는 연구들이 많이 수 행되어 왔다[1-3]. 반면 석탄폐석의 활용에 대한 연구는 외국에서는 토목분야, 시멘트원료, 요업분야, 세라믹골재, 공업원료 및 토목분야 등의 분야에 다각적으로 연구 개 
발되어 활용되고 있으나[4-6], 국내에서는 점토벽돌이나 경량골재와 같은 일반 요업제품의 원료로서의 일부 활용 외에는 오랫동안 연구가 제대로 이루어지지 않았으며[79], 따라서 실용화 기술개발의 부족 및 상품성 있는 제 품의 미개발로 인해 석탄폐석의 재활용이 제대로 이루어 지지 못했다. 다만 최근 들어 강원도 삼척, 도계 등의 폐광지역에 야적상태로 방치되어 있는 석탄폐석에 대한 재활용에 대해 관심도가 높아지면서 석탄폐석을 이용하 여 유리용 원료로 활용하기 위한 일부 연구들이 이루어 지고 있으며[10-12], 일부 유리공예품 및 유리타일과 같 은 제품들은 상용화가 이루어지고 있다. 본 연구에서는 광산에서 발생하는 석탄폐석을 활용하여 석탄폐석에 함 유된 실리카 $\left(\mathrm{SiO}_{2}\right)$ 성분과 알루미나 $\left(\mathrm{Al}_{2} \mathrm{O}_{3}\right)$ 성분을 기본 으로 타 원료를 조합한 후 용융하여 유리화를 시키고, 제조된 유리를 이용하여 보강재료로 사용할 수 있는 유 리섬유와 같은 2 차 제품을 개발함으로써 환경도 살리고 폐자원의 부가가치도 높일 수 있다는 면에서 연구를 진 행하였다.

유리섬유는 특성 및 화학조성에 따라서 A-Glass, CGlass, E-Glass, S-glass 그리고 AR-Glass 등으로 분류 할 수 있다. 이 중에서 현재 가장 많이 사용되고 있는 유리섬유는 E-Glass이다. 그 이유는 E-Glass fiber가 기 계적 강도, 전기적 특성, 화학적 특성 등 여러가지로 균형 된 특성을 보유하고 있어서 활용 면에서 매우 유용하기 때문이다. 전형적인 E-Glass의 화학조성은 $\operatorname{silica}\left(\mathrm{SiO}_{2}\right)$, alumina $\left(\mathrm{Al}_{2} \mathrm{O}_{3}\right)$, calcium oxide $(\mathrm{CaO})$, magnesium oxide $(\mathrm{MgO})$, boric oxide $\left(\mathrm{B}_{2} \mathrm{O}_{3}\right)$ 와 소량의 알칼리 $\left(\mathrm{Na}_{2} \mathrm{O} / \mathrm{K}_{2} \mathrm{O}\right)$ 로 구성되어 있고, $\mathrm{SiO}_{2}$ 함량 중에서 약 $6 \sim 8 \%$ 를 $\mathrm{B}_{2} \mathrm{O}_{3}$ 로
치환함으로써 유리의 용융온도 및 점도를 낮추는 효과를 나타내며, 동시에 알칼리 $\left(\mathrm{Na}_{2} \mathrm{O}, \mathrm{K}_{2} \mathrm{O}\right)$ 함량이 $1 \%$ 미만으 로 매우 낮아서 우수한 전기적 절연성을 갖는다. 이러한 유리섬유는 넓은 응용범위의 복합재료로서 사용되는데, 섬유강화플라스틱(FRP)의 보강재료로서 항공기, 자동차 그리고 다양한 레저용품 등에 널리 사용되고 있다[13].

\section{2. 실험방법}

유리제품을 만드는데 있어서 가장 중요한 것은 유리화 를 하기 위한 목표화학조성의 결정과 이 조성을 맞추기 위한 원료들의 배합비 선정이다. 원료의 합성비율을 어 떻게 하느냐에 따라서 목표하는 물리적, 화학적 특성을 갖는 유리를 제조 할 수 있으며, 해당 용융온도조건에서 양호한 특성을 갖는 투명한 유리를 제조할 수 있다[14]. 본 연구에서는 주 원료로서 석탄폐석을 사용하였으며, 석탄폐석 중에서도 카본 함량이 적은 사암계 석탄폐석을 사용하였다. 본 연구에서 사용한 사암계 석탄폐석의 화 학성분 분석치를 Table 1에 나타내었다. 또한 사용한 석 탄폐석을 이용한 유리조성 배합비를 Table 2에 요약하여 나타내었다. 유리화를 위한 유리조성 배합비는 목표 조 성계를 E-glass에 두고 석탄폐석의 투입량을 $0 ~ 35 \%$ 로 변화시켰으며 부족한 성분은 원료로 보충하여 배합비를 작성하였다. 대표적인 E-glass 배치조성은 규사, 석회석, 알루미나 등의 원료를 배합비에 맞춰 혼합하여 사용하고 있는데, 본 연구에서도 Table 2에서와 같이 일반 석탄폐 석을 주원료로 사용하고 여기에 규사 $\left(\mathrm{SiO}_{2}\right)$, 알루미나

Table 1

Chemical composition of refused coal ore (wt $\%$ )

\begin{tabular}{lllllllllll}
\hline & $\mathrm{SiO}_{2}$ & $\mathrm{Al}_{2} \mathrm{O}_{3}$ & $\mathrm{Na}_{2} \mathrm{O}$ & $\mathrm{CaO}$ & $\mathrm{K}_{2} \mathrm{O}$ & $\mathrm{MgO}$ & $\mathrm{TiO}_{2}$ & $\mathrm{Fe}_{2} \mathrm{O}_{3}$ & $\mathrm{SO}_{3}$ & $* \mathrm{Remarks}$ \\
\hline Refused coal ore (Normal) & 81.1 & 12.0 & 0.18 & 0.06 & 3.36 & 0.28 & 0.51 & 0.51 & 1.96 & $\mathrm{C}: 2.67$ \\
\hline
\end{tabular}

Table 2

Batch composition of E-glass samples

\begin{tabular}{llllllll}
\hline \multirow{2}{*}{ Raw materials } & \multicolumn{2}{l}{ Batch composition (wt\%) } & & \\
\cline { 2 - 6 } & CNEF-0 & CNEF-15 & CNEF-20 & CNEF-25 & CNEF-30 & CNEF-35 & \\
\hline Refused coal ore $(\mathrm{CN})$ & - & 15.00 & 20.00 & 25.00 & 30.00 & 35.00 & (Target of Glass \\
$\mathrm{SiO}_{2}$ & 28.50 & 17.30 & 13.00 & 8.60 & 4.20 & 0.00 & Composition) \\
$\mathrm{Al}_{2} \mathrm{O}_{3}$ & 7.50 & 5.70 & 5.00 & 4.40 & 3.80 & 3.00 & $\mathrm{SiO}_{2}: 54.5$ \\
$\mathrm{Na}_{2} \mathrm{CO}_{3}$ & 0.70 & - & - & - & - & - & $\mathrm{Al}_{2} \mathrm{O}_{3}: 14$ \\
$\mathrm{CaCO}_{3}$ & 20.00 & 20.00 & 20.00 & 20.00 & 20.00 & 20.00 & $\mathrm{Na}_{2} \mathrm{O}: 0.8$ \\
$\mathrm{~K}_{2} \mathrm{CO}_{3}$ & 0.20 & - & - & - & - & - & $\mathrm{CaO}: 22.1$ \\
$\mathrm{MgCO}_{3}$ & 0.77 & - & - & - & - & - & $\mathrm{K}_{2} \mathrm{O}: 0.2$ \\
$\mathrm{E}_{-} \mathrm{glass}_{3}$ cullet & 32.00 & 32.00 & 32.00 & 32.00 & 32.00 & 32.00 & $\mathrm{MgO}_{0} 0.6$ \\
$\mathrm{H}_{3} \mathrm{BO}$ & 10.00 & 10.00 & 10.00 & 10.00 & 10.00 & 10.00 & $\mathrm{TiO}_{2}: 0.5$ \\
$\mathrm{Fe}_{2} \mathrm{O}_{3}$ & 0.08 & - & - & - & - & - & $\mathrm{Fe}_{2} \mathrm{O}_{3}: 0.2$ \\
$\mathrm{TiO}_{2}$ & 0.25 & - & - & - & - & - & $\mathrm{B}_{2} \mathrm{O}_{3}: 6.6$ \\
\hline
\end{tabular}




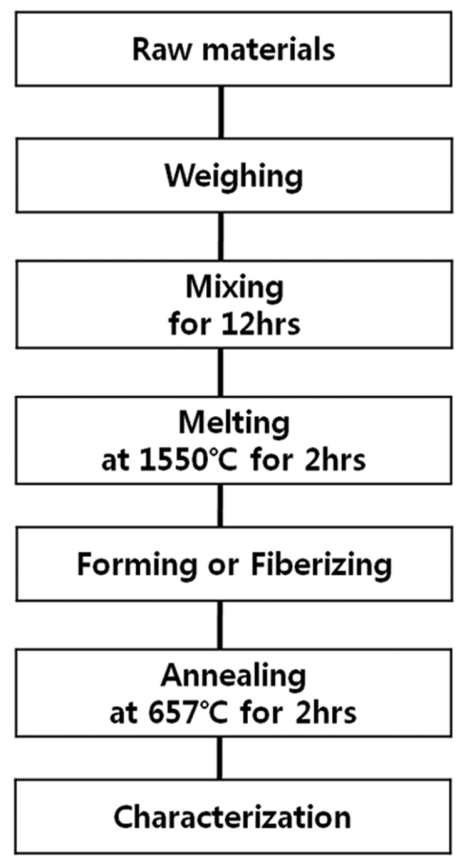

Fig. 1. Experimental procedure for preparing glass samples.

$\left(\mathrm{Al}_{2} \mathrm{O}_{3}\right)$, 탄산칼슘 $\left(\mathrm{CaCO}_{3}\right)$, 붕산 $\left(\mathrm{H}_{3} \mathrm{BO}_{3}\right)$ 과 E-glass 파유 리를 사용하였다. 파유리는 유리의 용융온도를 낮춰 용 융 속도를 빠르게 하고 유리의 균질도나 기계적 강도를 높이는 역할을 하며[15], 본 실험에서는 동일한 화학조성 을 갖는 E-glass 조성의 파유리를 사용하였다.

본 연구에 사용된 석탄폐석은 삼척 도계탄광에서 채취 한 석탄폐석을 사용하였다. 광물원료들은 입도를 균일하 게 제어하기 위하여 볼밀로 $300 \mu \mathrm{m}$ 이하로 분쇄하여 사 용하였으며, 분쇄된 광물원료와 화학원료 및 파유리를 Table 2에 나타낸 배합비로 배치 조합한 후 혼합하여 백금 도가니에 넣어 Fig. 1에 도식된 실험방법에 의해 박스형 전기로에서 $1550^{\circ} \mathrm{C}$ 2시간 동안 용융하였다. 용 융된 유리는 로에서 꺼내어 흑연 몰드 위에 부어 시편 을 제작하고, 성형된 시편은 응력제거를 위해 기존의 문 헌을 통해 알려진 'E-glass' 조성의 서냉온도(annealing temperature)인 $657^{\circ} \mathrm{C}$ 로 유지된 서냉로에 넣어 2 시간 동 안 유지한 후, 그 상태에서 그대로 자연로냉시켜 최종 유리샘플을 제조하였다[16]. 아울러서 섬유상태에서의 특성파악을 위해 용융된 모유리를 Fig. 2에서 나타낸 것 과 같은 별도의 실험실적 섬유인상장치를 제작하여 단일 섬유(single filament)를 제조하고, 그 특성을 평가하였다. 섬유의 인장강도를 측정하기 위하여 $20 \mathrm{~mm}$ 의 홈이 파 인 마분지에 한 개의 유리섬유시편을 중앙에 놓고 강력 접착제로 고정시켜 시편을 제작하였다. 이들 시편은 만 능시험기를 사용하여 $100 \mathrm{~N}$ 인 load cell 하에서 인장속 도를 $1 \mathrm{~mm} / \mathrm{min}$ 조건으로 강도를 측정하였고, 데이터의 신뢰도를 높이기 위하여 각 조성별로 30 개 이상의 시편

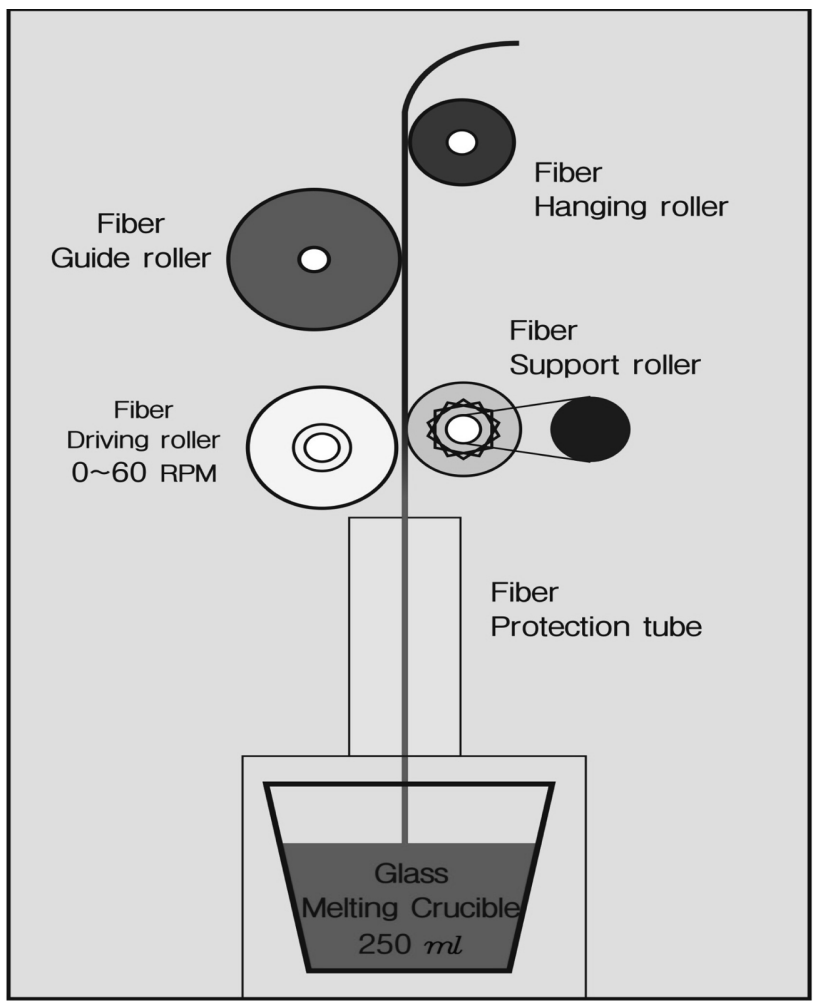

Fig. 2. Experimental fiberizing equipment of glass samples.

\section{을 측정한 후 평균값을 취하였다.}

제조된 유리시편에 대해서는 유리의 기본적인 열적특 성을 알아보기 위하여 TMA(Thermomechanical Analyzer: $\mathrm{Q} 400, \mathrm{TA}, \mathrm{USA})$ 를 이용하여 열팽창계수를 측정하였고, 연화점 측정기(SP-3A, ORTON, USA)를 이용하여 연화 점을 측정하였다. 또한 유리화 상태 및 광학적 특성을 알 아보기 위하여 유리시편을 $3 \mathrm{~mm}$ 로 일정하게 경면 연마 한 후 UV/VIS/IR Spectrometer(V570, JASCO, JAPAN) 을 이용하여 가시광선 영역에서의 광투과율과 컬러좌표 인 색도를 측정하였다. 그리고 유리조성에 따른 내화학 적 특성은 유리섬유시편을 이용하여 실시하였는데, 각 조성의 glass fiber 시편을 $5 \%$ 염산용액의 $90^{\circ} \mathrm{C}$ 온도조 건에 침적시킨 후 경과시간에 따라 섬유의 표면상태변화 를 현미경으로 관찰하였고, 이를 위하여 Field Emission Scanning Electron Microscope(FE-SEM, JSM 6700, $\mathrm{JEOL})$ 를 사용하였다. 섬유의 인장강도는 INSTRON(5544, 2712-013, USA)을 사용하여 측정하였다.

\section{3. 결과 및 고찰}

\subsection{E-glass의 화학조성}

유리가 매우 가는 섬유상이 되면 비표면적이 매우 커 


\begin{tabular}{|c|c|c|c|c|c|}
\hline ULEI KICEI KICE & KICET KICET KICET & <ICET KICET KICE》 & KICEI KICEI KICEI & ILEI KICEI KICE & KICEI KICEI KICEI \\
\hline ICET KICET KICE & KICET KICET KICET & 〈ICET KICET KICE] & KICET KICL KICET & IICET KICET KICE & LICET K.... KICET \\
\hline ICET KICET KICE & KICET KICET KICET & 〈ICET KICET KICE & KICET KICET KICE & IICET KICET KICE & [ICET KICET KICE] \\
\hline ICET KICET KICE & 〈ICET KICET KICET & ¿ICET KICET KICE' & KICET KICET KICE' & IICET KICET KICE & ¿ICET KICET KICE- \\
\hline 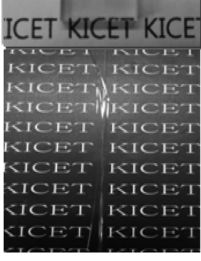 & 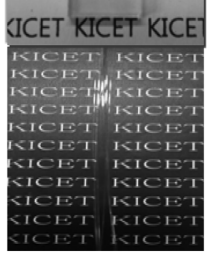 & 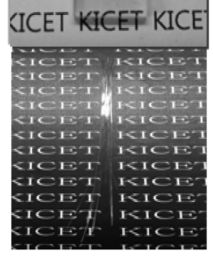 & 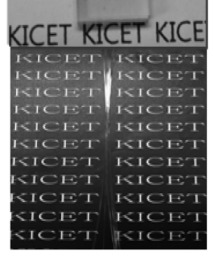 & 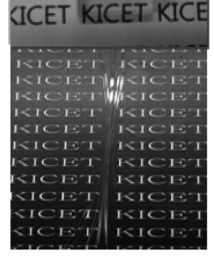 & 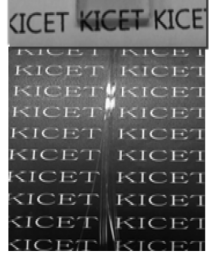 \\
\hline (a) & (b) & (c) & (d) & (e) & (f) \\
\hline
\end{tabular}

Fig. 3. Photographs of E-glass bulk and fiber samples: (a) CNEF-0, (b) CNEF-15, (c) CNEF-20, (d) CNEF-25, (e) CNEF-30 and (f) CNEF-35.

지지 때문에 대기에 의한 풍화, 약품에 대한 침식의 영 향이 크므로 화학적 내구성이 좋은 유리조성을 선택하여 야 한다.

그러나 한편 화학적 저항성이 강한 조성을 선택하면 섬유화에 대해 좋지 않은 물리적 성질을 띠기 쉬운 경향 이 생긴다[17].

석탄폐석은 카본함량이 낮은 사암계 석탄폐석과 상대 적으로 높은 셰일(shale)계 석탄폐석으로 나뉘어진다. 본 연구에서는 카본함량이 낮은 사암계 석탄폐석을 사용하 였으며, 화학조성분석 결과는 Table 1에서 볼 수 있듯이 $\mathrm{SiO}_{2}$ 와 $\mathrm{Al}_{2} \mathrm{O}_{3}$ 의 함량이 $81.1 \%$ 와 $12.0 \%$ 으로 나타났고, 카본함량은 $2.67 \%$ 로 나타났다. 카본 함량이 너무 높은 셰일계 석탄폐석이나 불균질한 석탄폐석을 사용하는 경 우, 유리화 과정에서 카본성분에 의한 환원작용에 의해 소위 'REDOX'라고 불리는 유리의 '산화환원상태지수' 조절이 어려워서 용융로의 온도 불안정 및 유리 내 기포 의 다량발생과 제거의 어려움 등과 같은 공정문제가 발 생할 수 있다. 이 경우에는 배치 조합에서 별도의 산화 제나 청징제의 추가 첨가와 같은 배치조성 설계를 통해 유리조성을 컨트롤해야 하나 본 실험에서는 카본성분이 낮은 사암계 석탄폐석을 사용하여 이러한 문제는 발생하 지 않았다.

본 실험에서는 기존에 널리 알려진 E-glass 조성을 목 표로 두고, 석탄폐석의 투입량변화에 따른 특성만을 확 인하기 위해 석탄폐석의 투입량을 원료배합비 기준으로 0 35\%까지 변화시키면서 석탄폐석의 주 성분인 $\mathrm{SiO}_{2}$ 와 $\mathrm{Al}_{2} \mathrm{O}_{3}$ 의 성분을 제외한 $\mathrm{CaCO}_{3}, \mathrm{H}_{3} \mathrm{BO}_{3}$, 파유리는 고정 하였으며, $\mathrm{CNEF}-0$ 의 경우는 석탄폐석을 사용하지 않기 때문에 화학원료와 파유리만을 사용하였다.

또한 석탄폐석 내에 존재하는 미량의 산화철 $\left(\mathrm{Fe}_{2} \mathrm{O}_{3}\right)$ 성분은 실험실적 실험에서는 의미가 없을 수도 있지만 향후 양산 제조시 불순물로서 산화철 성분의 영향을 파 악하기 위해 CNEF-0 조성에서는 추가로 첨가하여 사용
하였다. 각 조성별로 혼합된 배치를 용융한 후 성형하고, 서냉시킨 유리시편들은 Fig. 3(a) (f)의 윗 편 사진에서 나타난 바와 같이 연한 초록빛을 띄는 투명한 유리상태 를 나타내었다. 유리 시편 내에 부분적으로 기포가 포함 되어 있는 것이 관찰되었으나 미용융물이나 실투와 같은 입자들은 발견되지 않아서 완전한 유리화가 이루어졌음 을 판단할 수 있었다. 유리시편이 연한 초록빛을 띄는 이유는 배치조성에 포함된 산화철 $\left(\mathrm{Fe}_{2} \mathrm{O}_{3}\right)$ 성분의 영향이 라 판단되었으며, 섬유인상장치를 사용해 제조한 유리섬 유의 경우에는 Fig. 3(a) (f)의 그림에서 나타난 바와 같 이 육안상으로는 백색을 나타내는 유리섬유를 제조할 수 있었다.

\subsection{E-glass의 광투과율 특성}

본 연구에서는 석탄폐석 투입량에 따른 E-glass의 각 조성별로 시편의 유리화 상태 및 용융 상태를 파악하기 위해 용융유리 시편을 $3.0 \mathrm{~mm}$ 의 두께로 경면 연마한 후 spectrophotometer를 사용하여 가시광선 파장에서의 광 투과율을 측정하였다. Table 3과 Fig. 4의 그래프에서 보는 바와 같이 광투과율에 있어서 모든 시편의 가시광 선투과율 값이 81 84\%를 나타내어 상업용 투명 판유 리에서 나타나는 광투과율 수준과 거의 유사한 높은 값

Table 3

Light transmittance and chromaticity of E-glass samples

\begin{tabular}{lllll}
\hline \multirow{2}{*}{ Sample name } & \multirow{2}{*}{$\begin{array}{l}\text { Light transmittance } \\
(\%)\end{array}$} & \multicolumn{4}{l}{ Chromaticity } \\
\cline { 3 - 5 } & & $\mathrm{L}$ & $\mathrm{a}^{*}$ & $\mathrm{~b}^{*}$ \\
\hline CNEF-0 & 83.9 & 93.92 & -3.18 & 4.43 \\
CNEF-15 & 84.7 & 94.22 & -2.99 & 3.52 \\
CNEF-20 & 83.8 & 94.00 & -3.17 & 3.73 \\
CNEF-25 & 82.7 & 93.51 & -3.30 & 4.18 \\
CNEF-30 & 82.3 & 93.32 & -3.67 & 4.85 \\
CNEF-35 & 81.7 & 92.90 & -3.78 & 5.30 \\
\hline
\end{tabular}




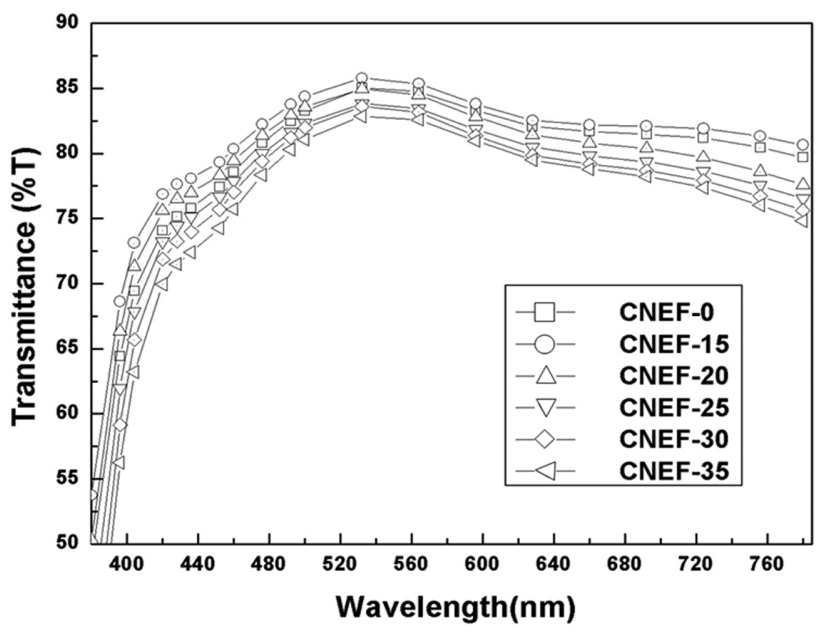

Fig. 4. Light transmittance of E-glass samples.

을 나타내었다. 그러나 석탄폐석을 $15 \%$ 투입한 CNEF15 와 $35 \%$ 투입한 CNEF-35를 비교해보면 석탄폐석의 투입량 증가에 따라 투과율이 약간씩 감소함을 확인 할 수 있다. 이는 석탄폐석의 투입량이 증가할수록 폐석이 갖고 있던 $\mathrm{Fe}_{2} \mathrm{O}_{3}$ 함량과 함께 카본의 함량이 증가함으 로 인해 유리의 산화환원 조건의 변화에 따른 착색 및 광차단 효과가 커졌기 때문으로 판단된다[10]. 그러나 석 탄폐석의 투입량 $20 \%$ 까지는 투과율 값이 CNEF-0와 거의 비슷하고 투입량 증가에 따라 그 변화의 폭이 크지 않아 별 문제가 되지 않을 것으로 판단되었다.

\subsection{E-glass의 색도(Chromaticity) 특성}

석탄폐석을 사용하여 제조된 E-glass가 광학적으로 어 느 정도의 색도를 나타내고, 폐석의 투입량변화에 따라 어떤 색변화를 나타내는지 확인하기 위한 방법으로 색좌 표(chromaticity diagram)를 이용한 칼라측정을 해 보았 다. Spectrophotometer를 이용하여 각 시편들의 색좌표
를 측정하였고, 이를 Fig. 5에 나타내었다. 그림에서 볼 수 있듯이 6 개 조성의 샘플 모두 순백색을 나타내는 ' 0 (제로)'의 좌표상에 거의 분포하고 있었으며, 산화철로 인한 착색으로 인해 좌표 값이 녹색방향으로 약간 치우 쳐 있는 것을 확인할 수 있었다. 용융유리에 대한 색차 값의 조성별 차이를 확인하기 위해 이들 좌표들을 확대 해서 분석해본 결과 명도를 나타내는 L값은 92.9 94.22, $\mathrm{a}^{*}$ 값에서 -3.78 -2.99로 거의 비슷한 수치를 나타내고 있었고, $b^{*}$ 에서는 $3.52 ~ 5.30$ 의 약간 퍼진 분포값을 나타 내었으나 육안 상으로 구분될 수 있는 편차는 아니어서 제품상으로는 별 문제가 되지 않으리라고 판단되었다.

\section{4. 유리의 열적 특성}

유리섬유의 열적 특성은 복합재료의 보강섬유로서 내 열성에 큰 영향을 미칠 뿐만 아니라 유리의 용융 및 유 리섬유의 섬유화 조건을 결정하는 인자로서도 매우 중요 한 의미를 갖는다. 따라서 유리섬유는 이러한 내열특성 에 따라 일반 E-glass fiber는 $830 ~ 860^{\circ} \mathrm{C}$ 정도의 연화점 을, 최근 개발된 새로운 E-glass fiber의 일종인 ' $\mathrm{BF}$ (Boron free)' E-glass fiber는 $916^{\circ} \mathrm{C}$, 고강도와 고내열의 S-glass fiber는 $1,050^{\circ} \mathrm{C}$ 이상의 연화점을 갖는다[18].

유리의 열적 특성으로서 연화점은 유리의 점도값이 $10^{7.6}$ poise인 온도를 나타내는 값으로서 유리의 작업점 (working point)과 함께 유리의 특성 및 제조공정을 결 정하는 데 중요한 값으로 여겨진다[19]. 제조된 유리샘플 의 조성별 연화점(Softening point)를 측정한 결과는 Table 4 에서 보는 바와 같이 $851 \sim 860^{\circ} \mathrm{C}$ 를 나타내었다. CNEF-15와 비교했을 때 석탄폐석의 투입량 증가에 따 라 연화점이 약간 낮아지는데 이는 석탄폐석이 갖고 있 는 알카리 성분 때문이라 판단된다. 6 개 조성 모두 목표 조성으로 E-glass 조성에 맞춰 배치조합을 설계하였으나, 석탄폐석 자체가 함유하고 있는 미량의 알카리 성분은
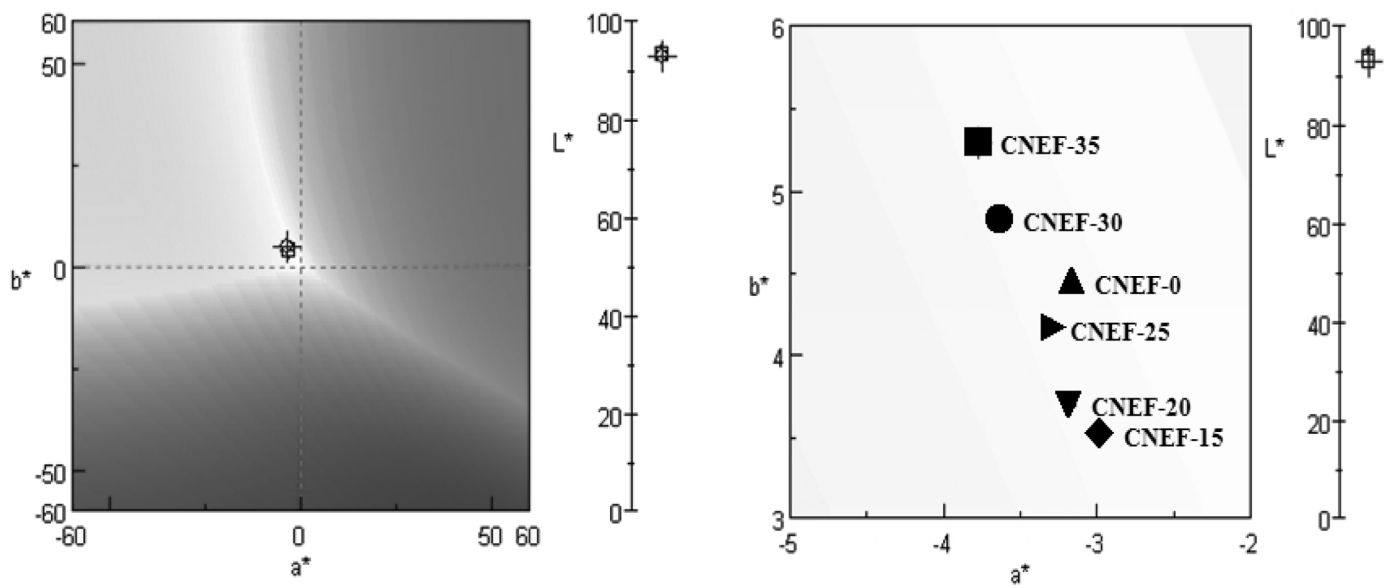

Fig. 5. Chromaticity of E-glass samples. 
Table 4

Thermal properties of E-glass samples

\begin{tabular}{lll}
\hline Sample name & $\begin{array}{l}\text { Softening } \\
\text { point }\left({ }^{\circ} \mathrm{C}\right)\end{array}$ & $\begin{array}{l}\text { Thermal expansion } \\
\text { coefficient }\left(\times 10^{-6}{ }^{\circ} \mathrm{C}\right)\end{array}$ \\
\hline CNEF-0 & 851 & 5.61 \\
CNEF-15 & 860 & 5.39 \\
CNEF-20 & 856 & 5.41 \\
CNEF-25 & 856 & 5.41 \\
CNEF-30 & 855 & 5.47 \\
CNEF-35 & 855 & 5.61 \\
\hline
\end{tabular}

투입량이 증가할수록 약간씩 증가하기 때문에 이로 인해 유리의 연화온도가 낮아지는 것으로 판단된다. 하지만 일반적인 E-glass 조성의 유리의 연화점이 제조업체나 문헌에 따라 $830 \sim 860^{\circ} \mathrm{C}$ 의 값을 나타내고 있으므로, 본 실험에서 얻어진 석탄폐석을 투입한 유리 샘플들은 모두 가 이러한 연화점 값들의 범위 내에 포함되어 있음을 확 인 할 수 있었다[18, 20].

또 하나의 열적 특성으로서 유리시편의 열팽창계수를 TMA(thermomechanical analyzer)를 이용하여 측정해 본 결과를 Table 3 에 나타내었다. 표에서 볼 수 있듯이 석탄폐석을 이용하여 제조된 'E-glass' 시편의 열팽창계 수는 조성별로 $5.39 \sim 5.61 \times 10^{-6} \rho^{\circ} \mathrm{C}$ 를 나타내었다. Table 4 에서 볼 수 있듯이 석탄폐석의 투입량이 증가할수록 열 팽창계수 값은 점차적으로 증가하는 경향을 나타내었다. 문헌상에 나타난 일반적인 E-glass fiber의 열팽창계수가 $4.9 \sim 6.0 \times 10^{-6} \%^{\circ} \mathrm{C}$ 정도이므로, 본 실험에서의 시편들은 문헌 값의 범위 안에 들어 있음을 알 수 있었다[16]. 유 리에서는 일반적으로 열팽창계수가 작을수록 열적 변화 에 대한 내열충격성이 크며, 내열충격성은 유리가 깨지 는 온도차 $(\Delta \mathrm{T})$ 로 표시되고, 아래 식에서와 같이 표현된 다[19].

$$
\Delta \mathrm{T}=\sigma(1-v) /(\mathrm{E} \cdot \alpha) \cdot \mathrm{S}
$$

( $\sigma$ : 파괴응력(인장강도), $v$ : 푸아송비(Poisson's ratio), $\mathrm{E}$ : 영률(Young's modulus), $\alpha$ : 선팽창계수, $\mathrm{S}$ : 시험편의 모양에 따라 달라지는 값)

따라서, 보강용 섬유로써 열적 특성이 섬유자체의 역 할에 큰 영향을 미치지는 않지만 열적 특성면에서 봤을 때 석탄폐석을 활용하여 제조된 E-glass는 기존의 'Eglass'와 비교해서 열적 특성상으로 충분히 양호한 특성 을 나타낼 수 있을 것으로 판단되었다.

\subsection{E-glass의 내화학특성}

일반적으로 섬유유리는 벌크(bulk) 상의 유리에 비해 비표면적이 크기 때문에 산 및 알칼리에 의한 침식성이 크다. 따라서 이러한 특성을 보완하기 위해서 시멘트 및
콘크리트의 보강용으로 사용되는 유리섬유는 AR(Alkali Resistant) glass fiber 라고 해서 지르코니아 $\left(\mathrm{ZrO}_{2}\right)$ 가 성 분이 함유된 특수한 조성의 유리섬유를 사용하고 있다 [21]. 반면에 일반적인 E-glass의 조성의 유리섬유는 산 (acid)에 용해되기 쉬운 성분이 포함되어 있어서 산과 접 촉되었을 때 유리섬유 표면에 균열이 발생하며, 유리섬 유의 전체적인 부식을 유발하고, 따라서 이러한 유리섬 유의 부식은 보강강화용으로써 복합재료 전체의 물성 저 하를 초래하는 결과를 나타낸다.

본 실험에서는 E-glass의 내화학특성 특성을 파악하기 위해서 Fig. 2에 나타낸 것과 같은 유리섬유인상장치를 통해 각 조성별로 유리섬유를 제조하고, $5 \%$ 염산용액의 $90^{\circ} \mathrm{C}$ 조건에서 각각의 섬유시편들을 침적시켰다가 20 분 180분 동안 일정시간에 샘플을 채취하여 섬유표면상태 의 변화를 현미경으로 관찰하였다. 이 중에서 석탄폐석 의 투입량에 따라 6가지 종류의 유리섬유 시편에 대해 각각 20 분, 40 분, 60 분, 120 분, 180 분 용액침적 후의 사 진을 Fig. 6에 나타내었다. 사진에서 볼 수 있듯이 침적 전 섬유의 표면상태는 모두 비교적 깨끗한 표면 상태를 나타내었으나 CNEF-0의 경우는 침적 후 20 분부터 침식 반응이 보이기 시작해서 침적 후 40 분 시편부터 표면에 미세한 균열이 발생함을 관찰할 수 있었으며, 180 분 경 과 후에는 표면의 박리현상으로 인해 섬유의 형상이 거 의 붕괴됨을 관찰 할 수 있었다. 반면 석탄폐석을 함유 한 CNEF-15 35까지는 샘플마다의 약간의 차이는 있지 만 120 분 경과 전까지는 표면에 큰 변화가 보이지 않았 으며, 120 분 경과 후부터 조성별로 침식반응이 발생하는 것으로 나타났으나, 180 분 경과 후에도 표면박리는 심하 게 발견되지 않았다. 따라서 석탄폐석을 사용하지 않은 일반 E-glass 섬유와 비교했을 때 석탄폐석을 함유해 제 조한 E-glass 섬유가 내산성 면에서는 현저하게 좋은 상 태를 나타냄을 알 수 있었다. 따라서 석탄폐석을 투입한 E-glass 조성의 유리섬유가 내 침식성면에서 우수하다는 것을 확인할 수 있었고, 이는 보강섬유로써 기존의 Eglass fiber보다 충분히 우수한 물성을 나타낼 수 있다고 판단되어진다.

\subsection{E-glass의 인장강도 특성}

유리섬유의 인장강도는 섬유화 과정에서 나타나는 유 리섬유 내의 기포와 같은 결함이나 냉각과정에서의 미세 한 크랙과 응력 등의 변수로 인해 많은 편차가 발생하게 된다. 따라서 인장강도 테스트를 위한 시편 제조 및 측 정오차를 줄이기 위해 각 조성별로 약 30 개 이상의 시 편을 제작하여 측정하였다. 또한 섬유의 직경에 따라 샘 플을 $140 \mu \mathrm{m}$ 이하와 그 이상으로 구분하여 측정하고 데 이터화 하였고, Table 5에 그 측정결과를 나타내었다. 


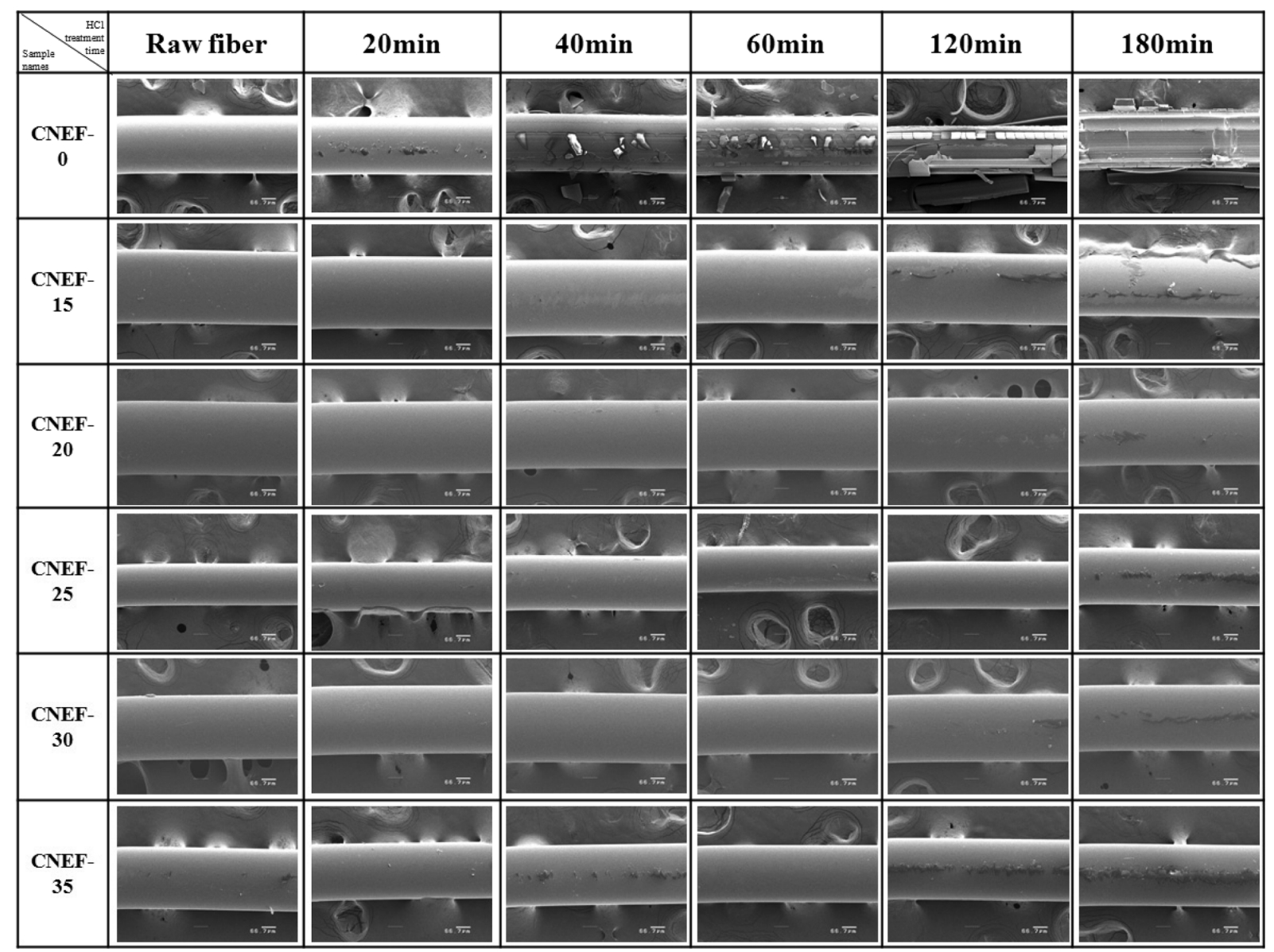

Fig. 6. SEM Photographs of E-glass fiber samples in $5 \% \mathrm{HCl}$ at $90^{\circ} \mathrm{C}$.

Table 5

Tensile strength of E-glass samples

\begin{tabular}{|c|c|c|c|c|c|}
\hline \multirow{3}{*}{$\begin{array}{l}\text { Sample } \\
\text { name }\end{array}$} & \multicolumn{4}{|c|}{ Strength with fiber diameter (MPa) } & \multirow{3}{*}{$\begin{array}{l}\text { Average } \\
\text { strength } \\
\text { (MPa) }\end{array}$} \\
\hline & \multicolumn{4}{|c|}{$\overline{90 \mu \mathrm{m} \leq \mathrm{D}<140 \mu \mathrm{m} 140 \mu \mathrm{m} \leq \mathrm{D}<190 \mu \mathrm{m}}$} & \\
\hline & (range) & (average) & (range) & (average) & \\
\hline CNEF-0 & $207 \sim 516$ & 371 & $209 \sim 332$ & 285 & 328 \\
\hline CNEF-15 & $261 \sim 563$ & 446 & $268 \sim 297$ & 292 & 369 \\
\hline CNEF-25 & $201 \sim 493$ & 330 & $218 \sim 278$ & 248 & 289 \\
\hline CNEF-30 & $247 \sim 455$ & 328 & $201 \sim 367$ & 239 & 284 \\
\hline
\end{tabular}

Table 5에서 볼 수 있듯이 섬유의 직경이 굵어지면 강도 값이 감소하는 경향을 확인 할 수 있다. 이는 Griffith가 제안한 이론에 의해 이해될 수 있다. 유리 표면에는 눈 에 보이지 않을 정도로 미세한 흠이 곳곳에 잠재하고 있 어 이들의 흠이 내응력을 크게 하는 작용을 한다. 이런 흠을 특히 Griffith's flaw라 한다. 굵은 섬유에서는 더욱 많은 flaw가 존재할 것이고 따라서 섬유의 굵기와 인장 강도와는 반비례 관계를 보여준다[23]. CNEF-0의 경우 를 봤을 때, $140 \mu \mathrm{m}$ 사이즈를 기준으로 약 $30 \%$ 정도 작은 값의 차이가 보인다. 석탄폐석의 투입량을 증가시 켰을 때에도 $140 \mu \mathrm{m}$ 사이즈를 기준으로 약간의 차이는
있지만 전체적으로 $25 \sim 30 \%$ 정도의 차이 값을 보이는 것을 관찰할 수 있었다. 석탄폐석의 투입량에 따른 섬유의 인장강도 값은, 석탄폐석을 사용하지 않은 $\mathrm{CNEF-0}$-에 비해 $\mathrm{CNEF}-15$ 는 약간 높은 값을, $\mathrm{CNEF}-25$ 와 $\mathrm{CNEF}-$ 30 은 약간 낮은 값을 나타냈다. 즉 평균강도를 봤을 때 석탄폐석의 투입량 $0 \%$ 에 비해 $15 \%$ 사용했을 때 강도 값이 약 $10 \%$ 정도 증가하여 조성 중 가장 높은 값을 나타내었고, 그 이상 석탄폐석의 투입량을 증가시켰을 땐 강도 값이 반대로 약간 감소하는 것을 볼 수 있었다. 물론 $15 \%$ 를 투입한 경우를 제외하고는 석탄폐석의 사 용에 따라 강도 값이 하락한다고 볼 수도 있지만, 실험 값으로 나온 강도 값의 차이가 크지 않기 때문에 석탄폐 석의 투입량이 강도 값에 큰 영향을 미친다고 단정하기 는 어려우며, 각각의 데이터가 갖는 최소 및 최대값을 비교해 보았을 때도 석탄폐석 투입량 증가와 강도와의 확실한 경향성을 확인할 수 없었다. 이는 앞에서 설명한 대로 유리섬유가 조성상의 특성 만이 아니라 섬유화 상 태에서 갖는 결함 및 여러 변수에 의해 큰 범위의 값을 나타내고 있으므로 단순 데이터의 평균 값으로 유리소재 의 비교평가를 하는 것도 바람직하지 않다고 판단된다. 따라서 여러 문헌들을 확인한 결과, 유리섬유의 인장강 
도에 대한 이러한 면에서의 고찰과 섬유의 강도 값을 단 일 평균값이 아닌 범위로 표시하는 것은 다른 문헌들에 서도 확인할 수 있었다[24, 25]. 결과적으로 석탄폐석의 투입 자체 및 투입량 증가가 유리섬유의 인장강도에 미 치는 영향은 그다지 크지 않음을 알 수 있었다. 그리고 본 실험에서는 직경 $100 \mu \mathrm{m}$ 대 $(90 \sim 190 \mu \mathrm{m})$ 의 섬유를 제조했지만, 향후 섬유화 온도 및 속도와 같은 방사조건 제어를 통해 다양한 직경의 섬유를 제조해 볼 예정이며, 이에 따라 현재 상용화 되어 있는 직경 수십 $\mu \mathrm{m}$ 의 미세 한 유리섬유들의 제조도 가능할 것으로 판단되었다.

\section{4. 결 론}

삼척지역에 폐기된 상태로 야적되어 있는 수억 톤에 달하는 석탄폐석을 재활용하기 위한 방안의 하나로서 석탄폐석의 주성분인 실리카 $\left(\mathrm{SiO}_{2}\right)$ 와 알루미나 $\left(\mathrm{Al}_{2} \mathrm{O}_{3}\right)$ 성분을 활용해서 E-glass 조성의 유리와 유리섬유를 제 조하였고, 그 특성을 측정하였다. 석탄폐석의 투입량을 0 35\%까지 변화시키면서, 각 조성의 배치를 $1550^{\circ} \mathrm{C}$ 에 서 2시간 용융한 결과 투명한 E-glass 조성의 유리를 얻을 수 있었다. 용융유리의 가시광투과율은 $81 \sim 84 \%$ 로 석탄폐석의 투입량이 $35 \%$ 까지도 높은 값을 유지했 으나 투입량이 증가할수록 투과율이 약간씩 감소하는 경향을 나타냈다. 열적특성인 연화점은 $850 \sim 860^{\circ} \mathrm{C}$ 로 석탄폐석의 투입량이 증가하면 약간씩 감소하는 경향으 로, 열팽창계수는 $5.39 \sim 5.61 \times 10^{-6} /{ }^{\circ} \mathrm{C}$ 로 석탄폐석의 투 입량이 증가함에 따라 약간씩 증가하는 경향을 나타내 었다.

또한 실험실적 섬유인상장치를 통해 제조한 유리섬유 의 내산성 실험에서 석탄폐석을 사용하지 않고 화학원료 만으로 제조한 CNEF-0 조성의 유리섬유는 염산용액 침 적 40분 경과 후부터 표면에 박리현상이 나타났고, 180 분이 지난 후에는 섬유형상이 붕괴됨을 확인할 수 있었 다. 반면에 석탄폐석을 첨가하여 제조한 조성의 유리섬 유는 180 분이 경과한 후에도 섬유표면에 미세한 균열현 상만이 발생하는 것으로 나타나서 훨씬 더 양호한 내화 학성을 나타내고 있음을 파악할 수 있었다. 보강섬유로 서 중요한 특성 중 하나인 인장강도의 경우, 섬유직경에 따른 차이는 나타났으나 석탄폐석의 투입량에 따른 섬유 의 인장강도 값은 큰 경향성을 나타내지 않았다. 결론적 으로 석탄폐석을 활용한 E-glass 조성의 유리는 양호한 용융상태와 기존의 E-glass와 거의 동등한 광학적, 열적, 강도 특성을 나타내었고, 양호한 내화학적 특성을 나타 냄으로써, 향후 섬유화에 대한 조건별 최적화 실험 및 양산 제조를 위한 추가 검토를 거쳐 충분히 실용화가 가 능할 수 있을 것으로 판단되었다.

\section{감사의 글}

본 연구는 한국세라믹기술원 '세라믹산업섬유실용화센 터 구축사업'으로 수행되었습니다.

\section{참 고 문 헌}

[1] Y. Ryu and Y. Kim, "A study on the surface modification of artificial lightweight aggregates by using bottom ash from coal power plant", Journal of the Korean Crystal Growth and Crystal Technology 19 (2009) 208.

[2] M. Song, J.B. Jang, B.S. Cho, J.H. Kim, Y.R. Kim and M.H. Kim, "An experimental study on properties of mortar using bottom ash produced in power plant", J. Architectural Institute of Korea 23 (2003) 202.

[3] K.D. Kim and S.G. Kang, "Manufacturing artificial lightweight aggregates using coal bottom ash and clay", Journal of the Korean Crystal Growth and Crystal Technology 17 (2007) 277.

[ 4 ] U.S. Patent 5,278,111 (1994).

[ 5 ] R.R. Menezes, H.S. Ferreira, G.A. Neves and H.C. Ferreira, "Use of granite sawing wastes in the production of ceramic bricks and tiles", J. Euro. Ceram. Soc. 25 (2005) 1149.

[6] M. Dondi, G. Guarini and I. Venturi, "Orimulsion fly ash in clay bricks-part 2: techmological behaviour of clay/ash mixtures", J. Euro. Ceram. Soc. 22 (2002) 1737.

[ 7 ] K.W. Kim, Y.S. Doh and X.F. Li, "Evaluation for characteristics of coal-mine waste concrete", J. Kor. Soc. Agricul. Eng. 43 (2001) 132.

[ 8 ] S.M. Han, D.Y. Shin and S.K. Kang, "Preparation for porous ceramics using low grade clay", J. Kor. Cer. Soc. 35(6) (1998) 575.

[ 9] KR Patent 101998033799 (1998).

[10] T.Y. Lim, S.S. Jeong, J.H. Hwang and J.H. Kim, "A study on the fabrication of soda-lime glass by using refused coal ore and its properties", J. Korean Crystal Growth and Crystal Technology 20(1) (2010) 43.

[11] T.Y. Lim, S.S. Jeong, J.H. Hwang, J.H. Kim and J.K. Kim, "Optical properties of soda-lime color glass fabricated by using refused coal ore", Kor. J. Mater. Res. 20(10) (2010) 524.

[12] T.Y. Lim, H.W. Ku, J. Hwang, J.H. Kim and J.K. Kim, "A study on the fabrication of foamed glass by using refused coal ore and its physical properties", J. Korean Crystal Growth and Crystal Technology 21(6) (2011) 266.

[13] J.S. Lee and T.Y. Lim, "Fabrication and characterization of boron free E-glass fiber compositions", Journal of the Korean Crystal Growth and Crystal Technology 23 (2013) 44.

[14] H.J. Jung, "Fusion ceramic materials (Text book for High School)", Ministery of Education Science and Technology (2003) 60.

[15] B.H. Kim, "Glass technology", Chungmoon Gak (2009) 25.

[16] F.T. Wallenberger, "Glass fibers", ASM Handbook 21 
(2001) 28.

[17] B.H. Kim, "Glass technology", Chungmoon Gak (2009) 430.

[18] F.T. Wallenberger, "Advanced inorganic fibers", Kluwer Academic Publishers (1999).

[19] H.J. Jung, "Fusion ceramic materials (Text book for High School)", Ministery of Education Science and Technology (2003) 193.

[20] T. Suzuki, "Data book of glass composition", The Glass Manufacturer's association in Japan (1991) 134.

[21] B.H. Kim, "Glass technology", Chungmoon Gak (2009)
380.

[22] F.T. Wallenberger, "Advanced inorganic fibers", Kluwer Academic Publishers (1999) 147.

[23] B.H. Kim, "Glass technology", Chungmoon Gak (2009) 393.

[24] F.T. Wallenberger, "Glass fibers", ASM Handbook 21 (2001) 28.

[25] J.R. Lee, J.S. Oh, S.J. Park and Y.K. Kim, "Effect of heat treatment condition on tensile strength of glass fibers", Proceeding of Autumn Annual Conference of KSCM (2002) 257. 